\title{
Implementasi E-Learning Dikaitkan Dengan Pengembangan Higher Order Thinking Skills
}

\author{
Fikri Aulia $^{\# 1}$, Wikan Budi Utami ${ }^{\# 2}$, Ponoharjo ${ }^{\# 3}$ \\ \#Bimbingan dan Konseling,,Universitas Pancasakti Tegal \\ Jl. Halmahera km. 1 Kota Tegal \\ Ifikri_aulia@upstegal.ac.id \\ *Pendidikan Matematika, Universitas Pancasakti Tegal \\ Jl. Halmahera km. 1 Kota Tegal \\ ${ }^{2}$ wikansatria@upstegal.ac.id \\ ${ }^{3}$ ponoharjo@gmail.com
}

\begin{abstract}
Abstact - This research is based on the rapid Information and Communication Technology in the world of education. This is contrary to the concept of 21 st century competence, one of which is mastering Information and Communication Technology. This research is motivated by the weakness of high level thinking skills or High Level Thinking Skills in FKIP Universitas Pancasakti Tegal students, specifically students in mathematics education. The purpose of this research is to study the implementation of Elearning based learning in improving Higher Level Thinking Skills in FKIP UPS Tegal students. This type of research is research and development. Affirmed by Borg and Gall (2003), that "educational research and development is a process used to develop and validate educational products". Furthermore they also put forward 10 steps of research and development, which can be simplified into the following five main steps: (1) analyzing the products to be developed; (2) developing initial products; (3) expert validation and revision; (4) small-scale field trials and product revisions; (5) large-scale field trials and final products. The results of calculations using SPSS software show a significance level of 0.135 or $13.5 \%$ or can be interpreted that e-learning is effective in improving mathematics learning outcomes in mathematics education students of the Faculty of Mathematics and Natural Sciences University of Pancasakti Tegal University. The most important thing in this e-learning learning experimental experiment is the superior sense that is encouraged by students to be taken and explored lecture material provided by the lecturer.
\end{abstract}

Keywords : Learning, E-Learning, HOTS

Abstrak - Penelitian ini didasari pada pesatnya Teknologi Informasi dan Komunikasi pada dunia pendidikan. Hal ini sejalan dengan konsep kompetensi abad 21, salah satunya adalah menguasai Teknologi Informasi dan Komunikasi. Penelitian ini dilatarbelakangi oleh lemahnya keterampilan berpikir tingkat tinggi atau Higher Order Thinking Skills pada mahasiswa FKIP Universitas Pancasakti Tegal, khususnya mahasiswa pada pendidikan matematika. Tujuan penelitian ini adalah untuk mengetahui pelaksanaan pembelajaran berbasis E-Learning dalam peningkatan Higher Order Thinking Skills pada mahasiswa FKIP UPS Tegal.. Jenis penelitian ini adalah penelitian dan pengembangan. Ditegaskan oleh Borg dan Gall (2003), bahwa “educational research and development is a process used to develop and validate educational products". Lebih lanjut mereka pun mengemukakan 10 langkah penelitian dan pengembangan, yang dapat disederhanakan menjadi lima langkah utama berikut: (1) melakukan analisis produk yang akan dikembangkan; (2) mengembangkan produk awal; (3) validasi ahli dan revisi; (4) ujicoba lapangan skala kecil dan revisi produk; (5) ujicoba lapangan skala besar dan produk akhir. Hasil penghitungan menggunakan perangkat lunak SPSS menunjukkan bahwa taraf signifikansi sebesar 0.135 atau $13.5 \%$ atau dapat dintepretasikan bahwa elearning efektif dalam meningkatkan hasil belajar matematika pada mahasiswa pendidikan matematika FKIP Universitas Pancasakti Tegal. Hal yang pling menonjol dalam pelaksanaan eksperimen pembelajarn e-learning ini adalah tingginya rasa terdorong mahasiswa untuk mengikuti dan mendalami materi perkuliahan yang telah disajikan oleh dosen.Abstrak ditulis dalam bahasa inggris dan indonesia.

Kata Kunci: Pembelajaran, E-Learning, HOTS

\section{PENDAHULUAN}

ini sesungguhnya memiliki kaitan secara langsung dengan peningkatan tahap literasi komputer, literasi informasi, dan

Meningkatnya kecenderungan manusia terhadap teknologi informasi dan komunikasi (TIK) di era informasi 
juga tingkat kesejahteraan masyarakat.

Kehadiran TIK dalam pendidikan bisa dimaknai dalam tiga paradigma, yaitu (1) TIK sebagai alat atau berupa produk teknologi yang bisa digunakan dalam pendidikan, (2) TIK sebagai konten atau sebagai bagian dari materi yang bisa dijadikan isi dalam pendidikan, dan (3) TIK sebagai program aplikasi atau alat bantu untuk manajemen yang efektif dan efisien dalam pendidikan[1]-[4].

Alasan problematik yang melatarbelakangi pentingnya pemanfaatan TIK dalam pendidikan, adalah (1) meningkatkan mutu layanan kepada seluruh masyarakat Indonesia tanpa mengenal suku, ras dan agama, (2) mengatasi kesenjangan layanan akibat kondisi geografis yang mana jika diabaikan akan menimbulkan disparitas mutu layanan, (3) perubahan sosio-budaya masyarakat yang bergerak dinamis, dan (4) memupuk rasa nasionalisme untuk menjaga kesatuan dan persatuan bangsa, dan (5) membangun kemandirian dan kreativitas[4]-[6].

Penelitian ini didasari pada pesatnya Teknologi Informasi dan Komunikasi pada dunia pendidikan. Hal ini sejalan dengan konsep kompetensi abad 21, salah satunya adalah menguasai Teknologi Informasi dan Komunikasi. Penelitian ini dilatarbelakangi oleh lemahnya keterampilan berpikir tingkat tinggi atau Higher Order Thinking Skills pada mahasiswa FKIP UPS Tegal, khususnya mahasiswa pada pendidikan matematika. Tujuan penelitian ini adalah untuk mengetahui pelaksanaan pembelajaran berbasis ELearning dalam peningkatan Higher Order Thinking Skills pada mahasiswa FKIP UPS Tegal.

\section{Tinjauan Pustaka}

Media pembelajaran melibatkan pengguna dalam aktivitas-aktivitas yang menuntut proses mental di dalam pembelajaran. Aktivitas mental spesifik yang dibutuhkan di dalam terjadinya pembelajaran dapat dibangkitkan melalui manipulasi peristiwa-peristiwa instruksional (instructional events) yang sistematis. Dalam hubungan ini Hooper menekankan peran penting suatu desain instruksional di dalam multimedia pembelajaran (educational multimedia). Dengan demikian multimedia pembelajaran adalah paket multimedia interaktif di mana di dalamnya terdapat langkahlangkah instruksional yang didisain untuk melibatkan pengguna secara aktif di dalam proses pembelajaran[1], [7], [8].

Istilah yang spesifik bagi suatu paket pembelajaran berbasis komputer adalah CAI (Computer Assisted Instruction), CAL (Computer Assisted Learning) atau CBL (Computer Based Learning). Paket-paket ini tidak secara eksplisit mencantumkan multimedia di dalamnya. Dengan demikian, paket-paket dapat merupakan multimedia dalam arti luas (mengandung teks, audio, animasi, video, bahkan simulasi) atau hanya terbatas mengandung beberapa media seperti teks dan gambar saja. Ketiganya secara eksplisit menekankan adanya instruksional yang didesain di dalamnya. Dengan kata lain di dalam pengembangan CAI, CAL atau CBL, suatu desain instruksional menjadi kerangka yang mencirikan paket-paket tersebut.

Adapun desain materi pembelajaran berbasis TIK, sebagaimana diidentifikasi oleh Munir (2008: 74-76) dikembangkan berdasarkan teori kognitif dan teori pembelajaran Adaptive Learning Theory, Preferred Modality Theory, dan Cognitive Flexibility Theory.

Adaptive Learning Theory memungkin peserta didik melalui pembelajaran dengan pengalaman belajar yang berbeda. Pengajar mencapainya dengan menggunakan berbagai materi dan strategi pembelajaran untuk membuat software pembelajaran. Untuk menggunakan teori ini, pengajar perlu memiliki pengetahuan tentang berbagai strategi dan pendekatan pembelajaran dalam membuat atau menyiapkan E-learning.

Prefered Modality Theory digunakan bagi pembelajaran di mana peserta didik mempunyai kecenderungan potensi kemampuan yang berbeda. Ini bermakna sebagaian peserta didik ada yang lebih meyukai belajar sambil mendengar atau sebagian peserta didik lagi lebih menyukai belajar sambil melihat dan mendengar. Dengan demikian, perancangan software perlu memuat kombinasi teks, grafik, suara dan animasi dengan bijak.

Menggunakan konsep kegunaan media komunikasi dalam pembelajaran sebagaimana diuraikan oleh Prawiradilaga dan Siregar, maka pelaksanaan pembelajaran di dapat memenuhi banyak fungsi yang bermanfaat bagi mahasiswa.

a. Memberikan Pengetahuan tentang Tujuan Belajar

Pada permulaan pembelajaran, mahasiswa perlu diberitahu tentang pengetahuan yang akan diperolehnya atau keterampilan yang akan dipelajarinya. Kepada mahasiswa harus dipertunjukkan apa yang diharapkan darinya, apa yang harus dapat ia lakukan untuk menunjukkan bahwa ia telah menguasai bahan pelajaran dan tingkat kemahiran yang diharapkan. Untuk pembelajran alam kawasan perilaku psikomotor atau kognitif, media visual khususnya yang menampilkan gerak dapat mempertunjukkan kinerja (performance) yang harus dipelajari mahasiswa. Dengan demikian dapat menjadi model perilaku yang diharapkan dapat dipertunjukkannya pada akhir pembelajaran.

b. Memotivasi Mahasiswa

Salah satu peran yang umum dari media komunikasi adalah memotivasi mahasiswa. Tanpa motivasi, sangat mungkin pembelajaran tidak menghasilkan belajar. Usaha untuk memotivasi mahasiswa sering kali dilakukan dengan menggambarkan sejelas mungkin keadaan di masa depan, di mana mahasiswa perlu menggunakan pengetahuan yang telah diperolehnya. Jika mahasiswa menjadi yakin tentang relevansi pembelajran dengan kebutuhannya di masa depan, ia akan termotivasi mengikuti pembelajaran. 
Media yang sesuai untuk menggambarkan keadaan masa depan adalah media yang apat menunjukkan (show) sesuatu atau menceritakan (tell) hal tersebut. Bila teknik bermain peran digunakan, pengalaman yang dirasakan mahasiswa akan lebih kuat. Film juga sering kali diproduksi dan digunakan untuk tujuan motivasi dengan cara yang lebih alami.

c. Menyajikan Informasi

Dalam sistem pembelajaran yang besar yang terdiri dari beberapa kelompok dengan kurikulum yang sama, media seperti film dan televisi dapat digunakan untuk menyajikan informasi. Guru kelas bebas dari tugas mempersiapkan dan menyajikan pelajaran, ia dapat menggunakan energinya kepada fungsi-fungsi yang alain seperti merencanakan kegiatan mahasiswa, mendiagnosa masalah mahasiswa, memberikan konseling secara individual. Ada tiga jenis variasi penyajian informasi: (a) penyajian dasar (basic), membawa mahasiswa kepada pengenalan pertama terhadap materi pembelajran, kemudian dilanjutkan dengan diskusi, kegiatan mahasiswa atau review oleh guru kelas; (b) penyajian pelengkap (supplementary), setelah penyajian asar dilakukan oleh guru kelas, media digunakan untuk membawa sumber-sumber tambahan ke dalam kelas, melakukan apa yang tidak dapat dilakukan di kelas dengan cara apapun; (c) penyajian pengayaan (enrichment), merupakan informasi yang bukan merupakan bagian dari tujuan pembelajran, digunakan karena memiliki nilai motivasi dan dapat mencapai perubahan sikap diri mahasiswa.

d. Merangsang Diskusi

Kegunaan media untuk merangsang diskusi sering kali disebut papan loncat (springboard), diambil dari bentuk penyajian yang relatif singkat kepada sekelompok mahasiswa dan dilanjutkan dengan diskusi. Format media biasanya menyajikan masalah atau pertanyaan, seringkali melalui drama atau contoh pengalaman manusia yang spesifik.

Penyajian dibiarkan terbuka (open-ended), tidak ada penarikan kesimpulan atau saran pemecahan masalah. Kesimpulan atau jawaban diharapkan muncul dari mahasiswa sendiri dalam interaksinya dengan pemimpin atau dengan sesamanya. Penyajian media diharapkan dapat merangsang pemikiran, membuka msalah, menyajikan latar belakang informasi dan memberikan fokus diskusi. Film atau video sering kali digunakan untuk tujuan ini.

e. Mengarahkan Kegiatan Mahasiswa

Pengarahan kegiatan merupakan penerapan dari metode pembelajaran yang disebut metode kinerja (performance) atau metode penerapan (application). Penekanan dari metode ini adalah pada kegiatan melakukan (doing). Media dapat digunakan secara ingkat atau sebentar-sebnetar untuk mengajak mahasiswa mulai dan berhenti. Dengan kata lain program media digunakan untuk mengarahkan mahasiswa melakukan kegiatan langkah demi langkah (step by step).

Penyajian bervariasi, mulai dari pembelajaran sederhana untuk kegiatan mahasiswa, seperti tugas pekerjaan rumah samapai pengarahan langkah demi langakh percobaan laboratorium yang kompleks. Permaianan merupakan metode pembelajran yang sangat disukai khususnya bagi mahasiswa sekoalh menengah, memiliki nilai motivasional yang tinggi, melibatkan mahasiswa lebih baik daripada metode pembelajaran yang lain.

f. Melaksanakan Latihan dan Ulangan

Dalam belajar keterampilan, apakah itu bersifat kognitif atau psikomotor, pengulangan respon-respon dianggap sangat penting untuk kemajuan kecepatan dan tingkat kemahiran. Istilah drill digunakan untuk jenis respons yang leboh sederhana seperti menerjemahkan kata-kata asing atau mengucapkan kata-kata asing. Practice biasanya berhubungan dengan kegiatan yang lebih kompleks yang membutuhkan koordinasi dari beberapa keterampilan dan biasanya merupakan penerapan pengetahuan, misalnya latihan olah raga tim atau individual, memecahkan berbagai bentuk masalah.

Penyajian latihan adalah proses mekanis murni dan dapat dilakukan dengan sabar dan tak kenal lelah oleh media komunikasi, khususnya oleh media yang dikelola komputer. Laboratorium bahasa juga salah satu contoh media yang digunakan untuk pengulangan dan latihan.

g. Menguatkan Belajar

Penguatan sering kali disamakan dengan motivasi, atau digolongkan dalam motivasi. Penguatan adalah kepuasam yamg dihasilkan dari belajar, di mana cenderung meningkatkan kemungkinan mahasiswa merespons dengan tingkah laku yamg diharapkan, setelah diberikan stimulus. Penguatan paling efektif diberikan beberapa saat setelah respons diberikan. Karena itu harus terintegrasi dengan fungsi media yang membangkitkan respons mahasiswa. Jenis penguatan yang umum digunakan adalah pengetahuan tentang hasil (kowledge of result).

Suatu program media bertanya kepada mahasiswa, kemudian mahasiswa menyusun jawabannya atau memilih dari beberapa kemungkinan jawaban. Setelah mahasiswa menentukan jawabannya, ia sangat termotivasi untuk segera mengetahui jawaban yang benar. Jika jawaban mahasiswa benar dan ia tahu, ia dikuatkan, bahkan jika jawabannya salah, evaluasi dari jawabannya, menunjukkan seberapa dekat jawabannya mendekati kebenaran, juga dapat menguatkan.

Media apa pun yang dapat digunakan untuk menyajikan informasi juga mampu menyajikan pertanyaan dan merangsang mahasiswa untuk menjawab. Media apapun yang melakukan fungsi ini, ia juga mampu memberikan jawaban benar terhadap responnya 
(actions or manipulations), sehingga memberikan latihan terhadap perilaku yang kompleks yang membutuhkan lingkungan khusus. Contoh yang sering ditemui adalah simulator mobil yang digunakan dalam latihan mengendara dan simulator pesawat yang digunakan untuk terhadap pertanyaan kognitif setelah mahasiswa diberi kesempatan menjawab, sehingga memungkinkan membandingkan dan memperoleh pengetahuan tentang hasil sesegera mungkin.

h. Memberikan Pengalaman Simulasi

Simulator adalah alat untuk menciptakan lingkungan buatan yang secara realistis dapat merangsang mahasiswa dan bereaksi pelatihan pilot. Instruktur biasanya menjadi bagian dari sistem, memberikan penilaian segera dan menyelipkan kerusakan pada sistem untuk memberikan mahasiswa latihan mengatasi masalah. Media komunikasi sering kali memegang peranan penting dalam simulasi, sejak mahasiswa harus mengkomunikasikan informasi kepada mesin dan sebaliknya mesin mengkomunikasikan informasi pengguna tentang pencapaiannya. Simulator tidak terbatas pada sistem yang kongkret dan self contained, tetapi dapat diaplikasikan pada sistem yang lebih abstrak seperti ekonomi nasional dari negara kuno, anggaran belanja sistem sekolah atau fungsi bantuan kedutaan dalam negara Afrika.

Program komputer dapat memungkinkan simulasi yang kompleks, menerima masukan mahasiswa, dan menghitung hasil dan menginformasikan kepada mahasiswa melalui media komunikasi tentang perubahan yang dilakukan dalam sisetem. Jenis lain dari simulasi adalah permainan, mensimulasikan sistyem yang kompetitif dengan dua atau lebih mahasiswa atau kelompok belajar berinteraksi satu sama lain. Karena sangat mirip dengan simulator yang dapat merefleksikan kenyataan, permainan dapat mengembangakan respons yang siap ditransfer ke dunia yang sebenarnya.

Media, biasanya film, video digunakan untuk merekam suatu pertemuan antara mahasiswa dan seseorang yang mensimulasikan kehidupan nyata seseorang, mahasiswa dilatih berinteraksi dengannya.

Selain menyiapkan e-learning, perlu juga pengembangan

HOTS bagi pembelajar dalam hal ini adalah mahasiswa, keterampilan berpikir tingkat tinggi didefinisikan sebagai keterampilan berpikir, penalaran, pemikiran kritis, dan pemecahan masalah[9], [10].

Beberapa faktor dapat menjelaskan pandangan keterampilan berpikir tingkat tinggi berkaitan tentang berpikir dan belajar yaitu :

1. Perbedaan jenis pembelajaran membutuhkan strategi pengajaran dengan metode tunggal yang dapat digunakan untuk semua pembelajaran, meskipun strategi khusus bekerja untuk tipe tertentu.

2. kecerdasan tidak lagi dilihat sebagai kemampuan untuk tidak berubah secara umum, melainkan sebuah kemampuan kaleidoskop yang dapat dipengaruhi oleh berbagai macam faktor, termasuk strategi pengajaran.

3. pemahaman tentang proses berpikir mempunyai pergeseran ke pandangan yang multidimensi- lebih seperti jaringan kompleks kemampuan interaktif daripada linear, hirarkis, atau proses spiral.

4. penelitian selama terakhir dua dekade telah difokuskan pada topik yang lebih khusus seperti wawasan, waktu tunggu untuk pemecahan masalah, citra visual dan metafora, dan skema

Dalam FCAT (Florida Comprehensive Assesmetnt Test), fokus pada keterampilan berpikir tingkat tinggi telah sangat nyata dalam matematika, di mana masalah kata yang lebih kompleks dan mengatasi situasi kehidupan nyata lebih dari tes sebelumnya.

Beberapa konsep utama yang relevan dengan kemampuan berpikir tingkat tinggi berdasarkan pada tiga asumsi tentang berpikir dan belajar.

Pertama, tingkat berpikir tidak bisa saling berhubungan dari tingkat pembelajaran; melibatkan saling keterkaitan, banyak komponen dan tingkat.

Kedua, apakah berpikir atau tidak berpikir bisa dipelajari tanpa subjek materi hanya berdasar titik teoritis. Dalam kehidupan nyata, siswa akan belajar konten di kedua komunitas di sekolah dan pengalaman, tidak peduli apa teori menyimpulkan, dan konsep-konsep dan kosa kata mereka belajar di tahun sebelumnya akan membantu belajar keterampilan berpikir tingkat tinggi dan konten baru tahun berikutnya.

Ketiga, berpikir tingkat tinggi melibatkan berbagai proses berpikir diterapkan kompleks situasi dan memiliki beberapa variabel.

Tabel I

Klasifikasi HOTS

\begin{tabular}{|c|c|c|}
\hline \multirow{3}{*}{ HOTS } & Mengkreasi & $\begin{array}{l}\text { - Mengkreasi ide/gagasan sendiri. } \\
\text { Kata kerja: mengkonstruksi, desain, kreasi, mengembangkan, } \\
\text { menulis, memformulasikan. }\end{array}$ \\
\hline & Mengevaluasi & $\begin{array}{l}\text { Mengambil keputusan sendiri. } \\
\text { Kata kerja: evaluasi, menilai, menyanggah, memutuskan, } \\
\text { memilih, mendukung. }\end{array}$ \\
\hline & Menganalisis & $\begin{array}{l}\text { Menspesifikasi aspek-aspek/elemen. } \\
\text { Kata kerja: membandingkan, memeriksa, , mengkritisi, } \\
\text { menguji. }\end{array}$ \\
\hline \multirow{2}{*}{ MOTS } & Mengaplikasi & $\begin{array}{l}\text { - Menggunakan informasi pada domain berbeda } \\
\text { Kata kerja: menggunakan, mendemonstrasikan, } \\
\text { mengilustrasikan, mengoperasikan. }\end{array}$ \\
\hline & Memahami & $\begin{array}{l}\text { Menjelaskan ide/konsep. } \\
\text { Kata kerja: menjelaskan, mengklasifikasi, menerima, } \\
\text { melaporkan. }\end{array}$ \\
\hline LOTS & Mengetahui & $\begin{array}{l}\text { - Mengingat kembali. } \\
\text { - Kata kerja: mengingat, mendaftar, mengulang, menirukan. }\end{array}$ \\
\hline
\end{tabular}

Sumber: Anderson \& Krathwohl (2001)

Beberapa konsep utama terkait keterampilan berpikir tingkat tinggi yaitu : [11]-[14]

1. Konteks

Berpikir tingkat tinggi tergantung pada konteks pada situasi dunia nyata dan memerlukan beberapa sebagai proses berpikir. Misalnya saat pergi ke kantin dan membuat keputusan tentang jenis dan jumlah makanan 
yang harus dimakan dibutuhkn pemikiran lebih kompleks saat dilanjutkan dengan menghitung karbohidrat dan lemak di kelas. Berpikir tingkat tinggi tergantung pada kemampuan individu untuk menerapkan, menata, dan memperkaya pengetahuan dalam konteks situasi berpikir.

2. Metakognisi

Sifat mengoreksi diri dari pemikiran disebut "metakognisi". Metakognisi termasuk kesadaran proses berpikir seseorang, self-monitoring, dan penerapan pengetahuan heuristic dan langkah berpikir. Keberhasilan seseorang dengan metakognisi tergantung, sebagian, pada keyakinan dan kemampuan seseorang untuk mendapatkan pengetahuan lebih serta kepercayaan dari orang lain, seperti guru, dalam kemampuan seseorang.

3. Pengetahuan Prosedural

Pengetahuan prosedural kadang-kadang disalahpahami sebagai keterampilan berpikir tingkat tinggi. Pengetahuan biasanya menjadi prasyarat untuk berpikir tingkat tinggi, pengetahuan tentang aturan dan aplikasinya. Kemampuan untuk membaca aturan atau kumpulan prosedur adalah " informasi belajar "; kemampuan untuk menerapkan aturan atau prosedur dalam situasi rutin tidak melibatkan keterampilan berpikir tingkat tinggi. Penerapan pengetahuan prosedural yang melibatkan analisis dan sintesis dari dua atau lebih konsep akan dianggap berpikir tingkat tinggi. Misalnya "Membangun proyeksi peta dan grid, menulis secara jelas dan melaporkan kasus ringkas, menghitung biaya overhead tetap untuk sebuah proyek, merancang spreadsheet, menggambar kesimpulan tentang dampak reformasi sosial pada universalitas program 16usic 16 , dan membangun hubungan yang berarti dengan rekan kerja .

4. Pemahaman

Pemahaman, bagian dari keterampilan berpikir tingkat rendah, merupakan bagian integral dari pengembangan keterampilan berpikir tingkat tinggi. Beberapa penelitian dan strategi pembelajaran fokus pada pemahaman seakan itu berada dalam domain yang lebih tinggi. Meskipun merupakan prasyarat penting, pemahaman bukan keterampilan berpikir tinggi. Pemahaman tetap proses dimana individu membangun makna dari informasi dan membentuk baru "schemata" melalui kegiatan tertentu.

\section{Kreativitas}

Meskipun beberapa referensi tidak secara eksplisit memasukkan kreativitas sebagai berpikir tingkat tinggi, kreativitas tidak dapat dilepaskan dari proses. Tindakan yang sangat solusi untuk menyelesaikan masalah membutuhkan proses kreatif melampaui konsep yang dipelajari sebelumnya dan aturan. Kreativitas melibatkan berpikir divergen dan konvergen untuk menghasilkan ide-ide baru.
6. Wawasan

Wawasan adalah solusi penyelesaian masalah yang tak terduga. Masalah kompleks ditemukan penyelesaian masalahnya melalui wawasan. Solusi bukan wawasan memerlukan penggunaan aturan, sementara solusi wawasan membutuhkan pemecahan masalah dan strategi kognitif. Dari perspektif lain, solusi noninsight membutuhkan pemahaman dan aplikasi, sementara solusi wawasan memerlukan analisis, sintesis, dan evaluasi seperti yang didefinisikan oleh Bloom

7. Intelijen

Tntelijen telah didefinisikan secara lebih. Intelijen tidak lagi terbatas pada gagasan tentang kemampuan tunggal atau kapasitas global untuk belajar, beradaptasi, dan berpikir rasional; inklusif dalam kemampuan umum dan khusus untuk merangkul pengetahuan umum, pemahaman, pemikiran, dan pemecahan masalah; multidimensi dalam proses mental yang melibatkan berpikir konvergen dan divergen; dan banyak tingkat, termasuk linguistic verbal, logis-matematis, spasial, music,-jasmani kemampuan kinestetik, interpersonal, dan intrapersonal yang mempengaruhi pendekatan seseorang untuk pemecahan masalah dan berpikir.

8. Pemecahan Masalah

Sebuah masalah adalah "situasi di mana individu ingin melakukan sesuatu tetapi tidak tahu bagaimana tindakan yang diperlukan untuk mendapatkan apa yang dia inginkan. Proses pemecahan masalah membutuhkan "serangkaian keputusan yang berurutan, masing-masing tergantung pada hasil dari sebelumnya

9. Berpikir kritis

Beberapa peneliti dan ilmuwan menggunakan istilah "berpikir kritis" dan "berpikir tingkat tinggi", sementara yang lain mendefinisikan "berpikir kritis" sebagai bentuk berpikir tingkat tinggi. Beberapa menggunakan istilah "berpikir kritis" dan "pemecahan masalah". Sebagian lagi menggangap, berpikir kritis adalah suatu bentuk pemecahan masalah. Yang lain mendefinisikan "berpikir kritis" sebagai bagian dari Proses evaluasi bukti yang dikumpulkan dalam pemecahan masalah atau hasil yang dihasilkan oleh berpikir kreatif.

\section{METODE PENELITIAN}

Jenis penelitian ini adalah penelitian dan pengembangan. Ditegaskan oleh Borg dan Gall (2003), bahwa "educational research and development is a process used to develop and validate educational products". Lebih lanjut mereka pun mengemukakan 10 langkah penelitian dan pengembangan, yang dapat disederhanakan menjadi lima langkah utama berikut: (1) melakukan analisis produk yang akan dikembangkan; (2) mengembangkan produk awal; (3) validasi ahli dan revisi; (4) ujicoba lapangan skala kecil dan revisi produk; (5) ujicoba lapangan skala besar dan produk akhir. 
Sampel yang digunakan dalam penelitian ini adalah mahasiswa pendidikan matematika FKIP UPS Tegal yang berjumlah 27 mahasiswa. Platform E-Learning yang digunakan adalah google classroom.

\section{HASIL DAN PEMBAHASAN}

\section{A. Pengembangan Media Pembelajaran E-Learning}

Media Pembelajaran E-Learning yang dikembangkan dalam penelitian ini adalah e- learning yang bertujuan meningkatkan HOTS mahasiswa dalam mata kuliah metode numerik semester 6. Prosesnya dilaksanakan melalui dua tahap berikut ini yaitu :

1. Persiapan dan Perancangan Desain

Kegiatan yang penulis tempuh sebelum penerapan adalah orientasi dan penyusunan rancangan desain. Orientasi desain pembelajaran dijalankan dengan cara memperkenalkannya kepada mahasiswa melalui diskusi. Rancangan desain berhubungan dengan rencana pelaksanaan perkuliahan. Komponen pembelajaran yang dikembangkan secara garis besar meliputi tujuan, materi, kegiatan, media, dan evaluasi pembelajaran.

Tujuan pembelajaran disusun mengacu pada learning outcome berdasarkan kurikulum yang berlaku. Pengembangan learning outcome diarahkan pada peningkatan HOTS siswa yang sangat berhubungan dengan proses belajar yang dilakukan mahasiswa.

Materi pembelajaran dalam desain pembelajaran ditentukan berdasarkan pokok bahasan yang akan dipelajari. Pembahasan tersebut bersumber learning outcome mata kuliah metode numerik sebagaimana tertuang dalam silabus. Untuk kepentingan penelitian ini ditetapkan materi perkuliahan Semester 6 Prodi Pendidikan Mateamtika, yaitu interpolasi

Kegiatan pembelajaran yang dikembangkan dalam pembelajaran terdiri dari lima tahapan. Setiap tahapan diwujudkan dalam beberapa kegiatan dosen dan mahasiswa. Media/alat dan sumber belajar yang digunakan dalam pembelajaran dalam penelitian ini meliputi: (1) buku sumber sebagai acuan untuk memahami teori dan praktik yang dipelajari; (2) media berupa presentasi powerpoint interaktif, google clasroom yang relevan dengan materi perkuliahan, dan penugasana mahasiswa.

Evaluasi yang digunakan mencakup evaluasi proses dan evaluasi hasil. Evaluasi proses dilaksanakan menggunakan instrumen berbentuk pedoman observasi selama kegiatan pembelajaran online berlangsung. Evaluasi hasil belajar dilakukan melalui prates dan pascates menggunakan bentuk tes objektif secara tertulis. Indikator penilaian HOTS meliputi pengetahuan materi, pemahaman, aplikasi, menganalisis, dan menerapkan konsep serta keterampilan mempraktikan materi pembelajaran sesuai dengan pedoman unjuk kerja yang ada.
2. Implementasi Desain Pembelajaran

Tahap implementasi pembelajaran dilakukan dengan pendekatan eksperimen. Pada tahap ini dikaji tentang keterlaksanaan pembelajaran yang dikembangkan, kemudian dilakukan penyempurnaan berdasarkan hasil pelaksanaan, diskusi.

Analisis perkembangan TIK merupakan analisis tambahan tentang kebutuhan dalam modifikasi model pengembangan pembelajaran berbasis TIK. Analisis ini bertujuan untuk mengetahui perkembangan teknologi informasi dan komunikasi (TIK) serta kesesuainnya dengan rencana media pembelajaran online yang akan dikembangkan, ada 3 analisis yang perlu dilakukan pada aspek perkembangan TIK, yaitu: (1) infrastruktur TIK, (2) aplikasi TIK, dan (3) sumber daya manusia. Infrastruktur. Analisis infrastruktur adalan analisis yang terkait dengan rencana penerapan pembelajaran berbasis TIK, dalam hal ini adalah perangkat-perangkat yang mendukung proses pembelajaran berbasis TIK, seperti sarana komputer yang terkoneksi dengan jaringan internet pada labortorium komputer, laptop mahasiswa, Wi-Fi dalam kampus maupun lingkungan sekitar kampus. Aplikasi TIK. Analisis aplikasi TIK adalah analisis yang berhubungan dengan content atau aplikasiaplikasi yang sesuai dan dapat digunakan oleh mahasiswa sebagai perangkat pembelajaran maupun sebagai sumber belajar. Khusus dalam analisis ini adalah pemilihan aplikasi TIK yang mendukung pembelajaran berbasis online dengan sistem media e-learning. Sumber daya manusia. Analisis ini merupakan analisis diri bagi seorang pengembang dengan mempertimbangkan kemampuan diri dalam penyusunan perangkat pembelajaran berbasis online.

Hasil kelima analisis ini kemudian dijadikan pertimbangan dalam melakukan pengembangan perangkat, pertimbangan tersebut dapat berupa alternatif pendekatan, metode dan strategi, perangkat pembelajaran, dan perangkat penilaian yang akan digunakan baik di dalam kelas maupun di luar kelas dengan sistem pembelajaran berbasis TIK

Efektivitas pembelajaran E-learning diuji melalui analisis komparatif atas data peningkatan hasil belajar siswa terhadap materi pelajaran sudut. Data tersebut diperoleh melalui tes yang dilakukan sebelum (prates) dan setelah (pascates) pembelajaran dilaksanakan.

Analisis data dilakukan melalui tahapan sebagai berikut: (1) mendeskripsikan data skor tes dari setiap mahasiswa; (2) menguji hipotesis dan mengukur signifikansi perbedaan skor prates dengan skor pascates

Tabel II

Hasil Pengolahan Data

Paired Samples Statistics

\begin{tabular}{c|c|c|c} 
Mean & $\mathrm{N}$ & $\begin{array}{c}\text { Std. } \\
\text { Deviation }\end{array}$ & $\begin{array}{c}\text { Std. Error } \\
\text { Mean }\end{array}$ \\
\hline
\end{tabular}




\begin{tabular}{ll|l|l|l|l}
\hline \multirow{2}{*}{ Pair 1 } & PT1 & 37.6667 & 27 & 28.34133 & 5.45429 \\
& PT2 & 74.8148 & 27 & 20.72538 & 3.98860 \\
\hline
\end{tabular}

\section{Paired Samples Correlations}

\begin{tabular}{l|l|r|r|r}
\hline \multicolumn{2}{|c|}{} & N & Correlation & \multicolumn{1}{c}{ Sig. } \\
\hline Pair 1 & PT1 \& PT2 & 27 & .295 & .135 \\
\hline
\end{tabular}

Paired Samples Test

\begin{tabular}{|c|c|c|c|c|c|c|c|c|}
\hline & \multicolumn{5}{|c|}{ Paired Differences } & \multirow[t]{3}{*}{$\mathrm{t}$} & \multirow{3}{*}{$\begin{array}{l}\mathrm{d} \\
\mathrm{f}\end{array}$} & \multirow{3}{*}{$\begin{array}{l}\text { Sig. } \\
(2- \\
\text { taile } \\
\text { d) }\end{array}$} \\
\hline & \multirow[t]{2}{*}{ Mean } & \multirow[t]{2}{*}{$\begin{array}{c}\text { Std. } \\
\text { Deviati } \\
\text { on }\end{array}$} & \multirow[t]{2}{*}{$\begin{array}{c}\text { Std. } \\
\text { Error } \\
\text { Mean }\end{array}$} & \multicolumn{2}{|c|}{$\begin{array}{l}95 \% \text { Confidence } \\
\text { Interval of the } \\
\text { Difference }\end{array}$} & & & \\
\hline & & & & Lower & Upper & & & \\
\hline $\begin{array}{ll} & \mathrm{PT} \\
\mathrm{Pa} & 1- \\
\text { ir } & \mathrm{PT} \\
1 & 2\end{array}$ & $\begin{array}{r}- \\
37.148 \\
15\end{array}$ & $\begin{array}{r}29.766 \\
66\end{array}$ & $\begin{array}{r}5.728 \\
60\end{array}$ & $\begin{array}{r}- \\
48.923 \\
45\end{array}$ & $\begin{array}{r}- \\
25.372 \\
85\end{array}$ & $\begin{array}{r}- \\
6.48 \\
5\end{array}$ & $\begin{array}{l}2 \\
6\end{array}$ & .000 \\
\hline
\end{tabular}

Hasil penghitungan menggunakan perangkat lunak SPSS menunjukkan bahwa taraf signifikansi sebesar 0.135 atau $13.5 \%$ atau dapat dintepretasikan bahwa elearning efektif dalam meningkatkan HOTS pada mahasiswa pendidikan matematika FKIP Universitas Pancasakti Tegal.

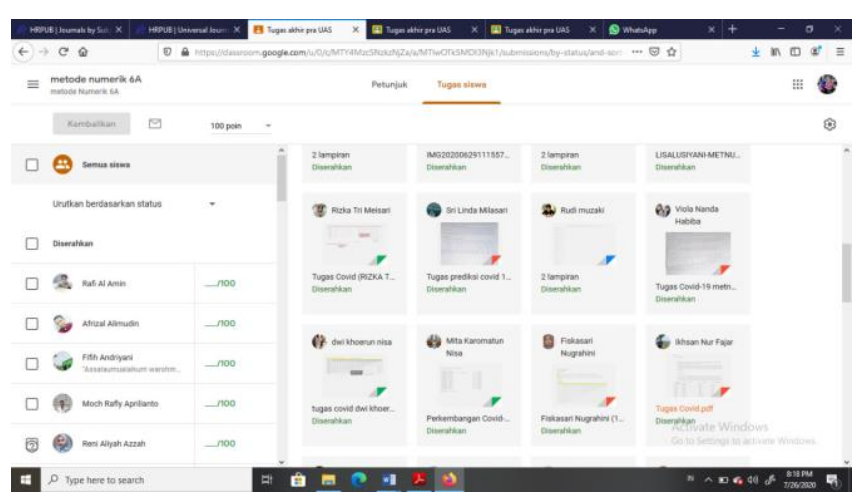

Gambar 1. Implementasi E-Learning

Setelah melaksanakan proses eksperimen penerapan pembelajaran e-learning dan pengujian efektivitasnya sebagaimana dideskripsikan di atas, maka penelitian ini telah menghasilkan e-learning yang dapat diimplementasikan untuk meningkatkan hasil belajar mahasiswa.

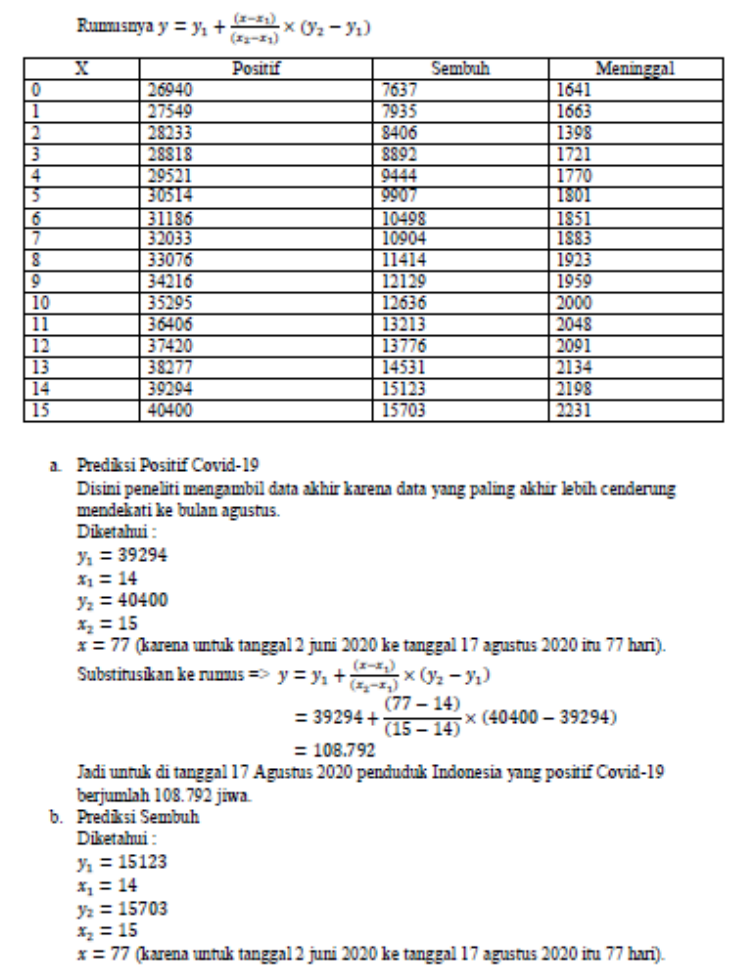

Gambar 2. Hasil jawaban soal HOTS

Dari hasil analisis uji soal dengan menggunakan soal HOTs menunjukkan bahwa rata-rata mahasiswa sudah mampu menjawab pertanyaan soal HOTs. Dimana mahasiswasudah mampu berpikir kreatif dan berpikir kritis dalam memecahkan permasalahan pada soal HOTs dimana mahasiswa telah memahami akan situasi yang dialami mahasiswa selama melakukan kegiatan pembelajaran. Sehingga kemampuan berfikir tinggi (Higher Order Thinking) digunakan apabila seseorang menerima informasi baru dan menyimpannya untuk kemudian digunakan atau disusun kembali untuk keperluan problem solving berdasarkan situasi. High Order Thingking Skills (HOTS) juga merupakan kemampuan untuk menghubungkan, memanipulasi, dan mengubah pengetahuan serta pengalaman yang sudah dimiliki secara kritis dan kreatif dalam menentukan keputusan untuk menyelesaikan masalah pada situasi baru. Dari pengambilan putusan yang dilakukan oleh mahasiswasecara kritis akan menimbulkan pola pikir mahasiswa pada kemampuan berpikir kreatif.

Oleh sebab itu pembiasaan dalam pemberian soal dan pembelajaran dengan HOTs akan menjadikan mahasiswamenjadi terbiasa berpikir kritis dalam menyelesaikan permasalahan dengan melakukan kemampuan berpikir kreatif dalam menemukan solusi yang diharapkan]. Serta melalui cara penilaian (soal-soal) menggunakan HOTs mahasiswaterus diasah dalam 
meningkatkan kemampuan berpikir kritis dan kreatif. Hal yang paling menonjol dalam pelaksanaan eksperimen pembelajarn e-learning ini adalah tingginya rasa terdorong mahasiswa untuk mengikuti dan mendalami materi perkuliahan yang telah disajikan oleh dosen. Meskipun demikian, efektivitas penerapannya mempersyaratkan kelengkapan materi perkuliahan yang disajikan oleh dosen, penyajian materi perkuliahan melalui e-learning oleh dosen, penyediaan waktu yang mencukupi oleh dosen untuk memberikan pengayaan materi perkuliahan, kecukupan waktu mahasiswa untuk mengajukan pertanyaan, mengulang dan berlatih materi perkuliahan, kemudahan mhasiswa untuk mendiskusikan dan menyimpulkan materi perkuliahan serta untuk mempraktikkan materi yang telah disajikan oleh dosen[1], [5], [15].

\section{KESIMPULAN}

Media pengajaran dalam sistem proses belajar mengajar mempunyai fungsi yang sangat penting, dalam hal ini media dapat digunakan agar lebih memberikan pengetahuan yang konkre Dari hasil penelitian dapat disimpulkan sebagai berikut Penilaian dan pembelajaran HOTs akan memberikan pengaruh terhadap perubahan kemampuan berpikir kritis dan kreatif dimana masing-masing mahasiswa diajak untuk melakukan pengembangan dan melatih kemampuan berpikir kritis dan kreatif mereka dalam menyelesaikan permasalahan yang diberikan. Dengan penilaian dan pembelajaran dengan menggunakan HOTS diharapkan pembelajaran menjadi bermakna dimana adanya interaksi aktif mahasiswadalam menggali pengetahuan dan pengalaman dalam pembelajaran yang telah diperoleh dan tepat serta mudah dipahami. pemanfaatan e-learning efektif dalam meningkatkan hasil belajar mahasiswa. Dosen memiliki kemampuan yang inovatif dalam menghidupkan suasana belajar yang lebih interaktif. Dan mahasiswa mampu mengembangakan HOTS yang dapat dilihat dari proses jawaban soal yang diberikan oleh Dosen.

\section{UCAPAN TERIMA KASIH}

Penulis ucapkan Terima kasih kepada seluruh civitas akademika Universitas Pancasakati Tegal yang terlibat dapat proses peneltian ini.

\section{DAFTAR PUSTAKA} Its Effects on Teaching and Learning in a Global Age," vol. 2, no. 1, pp. 203-210, 2012

[2] Č. Monika, "Analysis of Perceptions of Conventional and ELearning Education in Corporate Training," vol. 5, no. 4, pp. 73-
97, 2013.

[3] D. Karahoca, A. Karahoca, and A. Yücel, "Roles of teachers in elearning: How to engage students \& how to get free e-learning and the future," vol. 2, pp. 5775-5787, 2010.

[4] T. Panyajamorn, S. Suanmali, Y. Kohda, P. Chongphaisal, and T. Supnithi, "EFFECTIVENESS OF E-LEARNING DESIGN AND AFFECTING VARIABLES IN THAI PUBLIC SCHOOLS," vol. 15, no. 1, pp. 1-34, 2018.

[5] E. Galy, C. Downey, and J. Johnson, "The Effect of Using ELearning Tools in Online and Campus-based Classrooms on Student Performance," vol. 10, 2011.

[6] C. Wu, Y. Chen, and T. Chen, "An Adaptive e-Learning System for Enhancing Learning Performance: Based on Dynamic Scaffolding Theory," vol. 14, no. 3, pp. 903-913, 2017.

[7] M. Somayeh, M. Dehghani, F. Mozaffari, S. M. Ghasemnegad, H Hakimi, and B. Samaneh, "The effectiveness of E- learning in learning: A review of the literature $\mathrm{PhD}$ of nursing, Instructor, Department of nursing , Lahijan Branch , Islamic Azad university , Instructor, Department of Operating Room , Faculty of Medical Sciences , Birjand University of," pp. 86-91, 2016.

[8] E. Board, E. Editor, S. Editor, and M. Betz, "OF INSTRUCTIONAL TECHNOLOGY AND," 2015.

[9] A. H. Abdullah, M. Mokhtar, N. D. A. Halim, D. F. Ali, L. M. Tahir, and U. H. A. Kohar, "Mathematics teachers' level of knowledge and practice on the implementation of higher-order thinking skills (HOTS)," Eurasia J. Math. Sci. Technol. Educ., vol. 13, no. 1, pp. 3-17, 2017.

[10] R. O. Akbar and R. Tsoraya, "Pengaruh Kemampuan Berfikir Statistik terhadap Kreativitas Berfikir Siswa dalam Matematika (Studi Kasus di Kelas XI IPA MAN 2 Kota Cirebon)," Eduma, vol. 2 , no. 2,2013

[11] M. Hugerat and N. Kortam, "Improving higher order thinking skills among freshmen by teaching science through inquiry," Eurasia J. Math. Sci. Technol. Educ., vol. 10, no. 5, pp. 447-454 2014.

[12] A. Maharaj and V. Wagh, "Formulating tasks to develop HOTS for first-year calculus based on Brookhart abilities," S. Afr. J. Sci., vol. 112 , no. $11-12$, pp. $1-7,2016$

[13] Nasrun, "Contextual Learning Approach in Improving Critical Thinking Skills of Guidance and Counseling Students of State University of Medan," Int. J. Sci. Basic Appl. Res., vol. 18, pp. 151-161, 2014.

[14] M. Pinho-lopes and J. Macedo, "Project-Based Learning to Promote High Order Thinking and Problem Solving Skills in Geotechnical Courses," Int. J. Eng. Pedagog., vol. 4, no. 5, pp. 20-28, 2014.

[15] M. L. Cheok, "Predictors of E-Learning Satisfaction in Teaching and Learning for School Teachers : A Literature Review," vol. 8 , no. 1, 2015.

[16] Prawiradilaga dan Siregar. 2004. Mozaik Teknologi Pendidikan. Jakarta:Kencana. 